\title{
Śmierć, śmierć, inne życie. Wieś w literaturze polskiej przełomu XX i XXI wieku
}

\author{
Przemysław Czapliński
}




\section{Szkice}

\section{Śmierć, śmierć, inne życie. Wieś w literaturze polskiej przełomu XX i XXI wieku}

Przemysław Czapliński

TEKSTY DRUGIE 2017, NR 6, S. 13-35

DOI: $10.18318 /$ td.2017.6.2

W szystko, co chciałbym powiedzieć w niniejszym tekście, da się rozpakować z trzech tez wyjściowych. Sądzę, po pierwsze, że w latach 9o. zanikła literatura chłopska (jako zbiór poetyk i jako instytucja życia literackiego); po drugie - w jej miejsce weszła, korzystająca z dziedzictwa, acz nie występująca w roli dziedzica, literatura przedstawiająca wieś; po trzecie - literatura ta, tworzona przez osobnych pisarzy, pozbawiona wyrazistych celów, lokuje się w polskim życiu literackim jako mediator między dyskursami zarządzającymi wizerunkiem wsi i decydującymi o jej losie'.

Moment zmiany lokuję w połowie lat 9o., ponieważ właśnie wtedy jawny stał się kryzys samoreprezentacji kultury chłopskiej w komunikacji zbiorowej. Trzy powiązane ze sobą instancje przedstawiania wsi

1 Krótkie dzieje literatury o wsi 1995-2017 dzielę na wątki raczej niż etapy. W artykule nie przedstawiam więc syntezy historycznoliterackiej, lecz posługuję się metodą przeglądarki pojedynczych tekstów dla sformułowania uogólnień.

\section{Przemysław}

Czapliński - historyk literatury XX i XXI wieku, eseista, tłumacz; współtwórca Zakładu Antropologii Literatury (UAM Poznań). Ostatnie publikacje: Polska do wymiany (2009), Resztki nowoczesności (2011), Literatura ustna (2011), Kamp. Antologia przekładów (współredaktor A. Mizerka, 2013), Poetyka migracji (wespół z Renatą Makarską i Martą Tomczok, 2013), Poruszona mapa (2016). 
w dotychczasowym układzie - pisarze, współtworzone przez nich społeczne instytucje (wydawnictwa, czasopisma, kręgi odbiorców, programy nauczania, nagrody) oraz style opowieści - przestały działać. Wybitni i ważni twórcy ${ }^{2}$ (Myśliwski, Pilot, Nowak) milczeli, czasopisma funkcjonowały na marginesach marginesów, nagrody literackie specyficzne dla tego obiegu (im. Reymonta czy Piętaka) utraciły swoją siłę rekomendacyjną w szerszym polu. Przedłużał się zatem czas nieobecności - jakby dotychczasowe techniki transpozycji doświadczenia chłopskiego na literaturę wymagały odnowienia w zmienionej rzeczywistości. Pisarze nie decydowali już o obliczu wsi, nie desygnowali tematów i problemów, a ich ewentualne wypowiedzi nie były przekazywane dalej przez media. Pas transmisyjny biegł raczej od polityków i ekonomistów do mediów i świadomości publicznej, nie zaś od literatury.

Późniejsze wydarzenia literackie z połowy lat 9o. nie miały charakteru rewolucyjnego i nie utworzyły mocnej cezury. Jak większość pojedynczych elementów, które tworzą przypadkowe konstelacje w historii literatury, zasługują one na miano symptomów, a nie działań wytwarzających nowy stan rzeczy zamierzony przez pisarzy. A jednak warto je tu zgromadzić dla uświadomienia, że w hałaśliwej ciszy, jaka zapadła wokół wsi ${ }^{3}$, niewiele głosów było trzeba, aby zainicjować nowy początek. Starczyły trzy książki prozatorskie i jeden reportaż filmowy: Opowieści galicyjskie (1995) Andrzeja Stasiuka, Prawiek i inne czasy (1996) Olgi Tokarczuk, Widnokrąg (1996) Wiesława Myśliwskiego oraz quasi-dokument Arizona (1997) Ewy Borzęckiej.

Zacznijmy od Widnokręgu. Myśliwski po powieści Kamień na kamieniu funkcjonował w polskim życiu literackim jako dysponent głębokiej prawdy o wsi polskiej. Korzystał z tego przywileju bardzo oszczędnie, pracując wytrwale jako redaktor książek oraz kwartalnika „Regiony” - nad dokumentowaniem chłopskiej kultury. W tym właśnie kontekście symbolicznej rangi nabiera fakt,

2 W. Myśliwski następną książkę po powieści Kamień na kamieniu (1984) opublikował w roku 1996 (Widnokrąg); Marian Pilot: 1989 - Bitnik Gorgolewski, 2002 - Na odchodnym: opowieści i opowiadania; Tadeusz Nowak zmarł w roku 1991 (ostatnia powieść - Wniebogłosy - ukazała się w 1982; pośmiertnie, w roku 1999, wydano Jeszcze ich słyszę, widzę jeszcze. Jak w rozbitym lustrze).

3 Rozumiem przez to brak nowego dyskursu na temat wsi w warunkach dominacji wizerunku chłopów jako klasy roszczeniowej. Zob. Czy polska wieś potrzebuje nowej polityki kulturalnej, Paweł Staniurski rozmawia z prof. Wojciechem J. Bursztą, "Kultura Wsi” 2014 nr 1, s. 8: „w pierwszych 10-15 latach transformacji ustrojowej w polskiej etnologii i socjologii nastąpił właściwie całkowity zanik badań nad wsią". 
że powieścią Widnokrąg, uwieńczoną nagrodą Nike w roku 1997, pisarz zrzekał się niejako monopolu na pisanie o chłopskim życiu.

Akcja Widnokręgu toczy się w środowisku małomiasteczkowym. Właśnie tam pisarz osadził kulturę żywej opowieści, którą od początku swojej twórczości przedstawiał jako fundament kultury chłopskiej. Transfer ten, a także natychmiastowa konsekracja dokonana przez jury najsilniejszej nagrody literackiej, czyściły pole dla innych reprezentacji kultury chłopskiej. Nie chodzi tu oczywiście o kompletne spustoszenie, lecz raczej o społeczne oczekiwanie na zmianę, które nadawało układowi komunikacyjnemu pozory większej głębi i rozległości. Sprzyjało to młodym pisarzom, którzy ani czekali na przyzwolenie ze strony starszych, ani specjalnie zastanawiali się nad konfiguracją nazwisk, tematów i pozycji.

\section{Śmierć po raz pierwszy albo: czy pegeery mogą zostać zbawione}

Opowieści galicyjskie $e^{4}$ ze względu na pozycję opowiadacza i świat przedstawiany - wpisywały się w rozmaite tradycje. Pisarz kierował nasze skojarzenia w stronę rzeczy nieopowiadalnych, niezarejestrowanych w bibliotece, ale myśl czytelnika mogła pobiec ku znanym kontekstom - ku Ludziom stamtąd Marii Dąbrowskiej, czyli zapiskom obserwatora odkrywającego dolne warstwy nędzy i poniżenia, albo ku Opowieściom leskim Włodzimierza Odojewskiego, który korzystając z prawa do konfabulacji, ujmował w klasowe kategorie relacje między Ukraińcami i Polakami.

U Stasiuka nie ma ani tej bezstronności otwartej na wstyd, co u Dąbrowskiej, ani tego zbliżania się do zagadki nienawiści, co u Odojewskiego. Autor Opowieści galicyjskich wybrał poetykę „obrazków rodzajowych” i „portretów imiennych", chcąc zrozumieć miejsce, do którego przybył, i ludzi, obok których postanowił zamieszkaćs. Ale tropy wiodły od osób do szerszej historii, więc portrety zaczęły sumować się w podziurawioną panoramę wsi popegeerowskiej. Wsi od zawsze niedorobionej, a teraz coraz bardziej zrujnowanej („Kilka budynków - ciężkich barek, liszajowatych i nędznych, uwięzionych w podróży donikąd, unieruchomionych na gigantycznej białej fali", OG 12), umiejscowionej gdzieś w pół drogi między Galicją i PRL-em, obnażonej w momencie, gdy odchodzi „komuna” i pojawia się kapitalizm. Ten obraz

\footnotetext{
4 A. Stasiuk Opowieści galicyjskie (1995), Wydawnictwo Czarne, Wołowiec 2012, ebook. Lokalizacja cytatów bezpośrednio $w$ tekście po skrócie OG.

5 Zob. J. Jarzębski Apetyt na przemianę. Notatki o prozie współczesnej, Znak, Kraków 1997, s. 144.
} 
„pegeerowa” na przełomie epok gospodarczych wypadł - bez względu na intencje pisarza - neokolonialnie. Ludzie, o których opowiada narrator, mają swoje imiona i skrótowe biografie, ale nie są do końca ludźmi. Między członkami gromady nie ma różnic istotniejszych niż te, które nie różnicują - ile kto potrafi wypić wódki, jak długo wytrzyma na mrozie, ile paliwa opchnie „na lewo".

Okrucieństwo tych opisów nie służy prowokacji. Stasiukowy narrator stylizuje się raczej na obserwatora, który chce uwznioślić przedstawianą gromadę. Szukając wyjścia z pułapki naturalizmu, sięgnął po kontekst biblijny i opowiedział historyjki o istotach pierwotnych - tak ściśle zjednoczonych z naturą, że wolnych od moralności i grzechu. Byli niewinni, ponieważ skazano ich na życie, które wymagało raczej instynktów niż świadomości. Okazali się winni, gdy nowy bóg postanowił zlikwidować ten zdezelowany raj leżący poza czasem. Nadszedł potop, a potem nastąpiło nowe stworzenie świata. Jednakże zagłada jest realna, a zbawienie oszukańcze. Potop zalewa resztki wspólnego - i wspólnie rozkradanego - majątku, a tęcza pojednania rozświetla kiosk z najtańszymi towarami.

Zestawienie Myśliwski-Stasiuk wydaje się na pierwszy rzut oka karkołomne, a jednak porównanie warte jest ryzyka. Bo Stasiuk sprawia wrażenie anty-Myśliwskiego - pisarza, który przeszedł na drugą stronę obrazu z Kamienia na kamieniu. Zamiast wsi, w której każda rodzina trudzi się na własnym polu, mamy u Stasiuka demoralizujący wpływ własności wspólnej, którą wszyscy uważają za niczyją; zamiast przywiązania „do ziemi, do języka, do wiary"6 - brak jakiegokolwiek poczucia jedności z ziemią, pamięć sięgająca zeszłego roku, wydziedziczenie z wszelkich tradycji. U Myśliwskiego najważniejsze dziedzictwo to kultura wyjaśniająca świat i pozwalająca w nim zamieszkać, u Stasiuka - obcość, poczucie wydziedziczenia, kultura lewizny. Myśliwski akcentuje spójność i samodzielność świata chłopskiego, Stasiuk opisuje społeczność reaktywną, dostosowującą się do warunków. Obraz wsi pegeerowskiej - której Myśliwski nigdy nie chciał wpuścić na karty swoich powieści - powraca tu jako wyparte powojennej kultury chłopskiej.

6 W. Myśliwski Kres kultury chłopskiej, "Twórczość" 2004 nr 4, przedruk W: "Gazeta Wyborcza” 22-23.05.2004, s. 19: „W dużej mierze to dzięki chłopom Polska przetrwała. Dzięki ich przywiązaniu do ziemi, do języka, do wiary. Na tych trzech bowiem fundamentach zasadzało się chłopskie trwanie tu i zawsze, z dziada pradziada, niezależnie od tego, czy Polska była matką czy macochą, czy w ogóle była". 
Najważniejsza różnica tkwi jednak w motywie cmentarnym, który pojawia się w powieści Kamień na kamieniu i w Opowieściach galicyjskich. Bohater Myśliwskiego - potężna osobowość, choć niewyraźny człowiek - u kresu swojego życia chce dokończyć budowę rodzinnego grobowca, aby poprzez ten symboliczny gest połączyć rozproszoną (i skonfliktowaną) rodzinę, a także by, nadal symbolicznie, sporządzić kryptę, w której zdeponuje kompletną opowieść. Epos poświęcony kulturze chłopskiej jest tu składany do grobu na znak końca, lecz także dla potwierdzenia dumnej autarkii - eschatologicznej samowystarczalności chłopskiego kosmosu. Pisarz dawał w ten sposób do zrozumienia, że koniec kultury chłopskiej wymaga spowiedzi i odpuszczenia grzechów, który to sakrament dokonuje się w ramach systemu symbolicznego wypracowanego przez kulturę chłopską.

Ten sam motyw - odprawiania pochówku - pojawia się u Stasiuka. Kontekst jest jednak diametralnie różny. Oto pewien wiejski robotnik sezonowy, ani lepszy, ani gorszy od innych, co to pił i bił w normie, zadźgał nożem sąsiada. Poszedł do więzienia, w czasie przepustki zamarzł w polu. Wraca jako duch: pokazuje się kelnerce, a sierżanta policji prosi o "mszę za duszę". Nie za darmo: gotów jest powiedzieć, kto naprawdę zawinił w sprawie (dwóch rywali, jedna kobieta, morze wódki), która rozegrała się już po jego śmierci, a której - jako niematerialny duch - był świadkiem. Wątek zbłąkanej duszy proszącej o mszę - głęboko zakorzeniony w kulturze polskiej, a dla Stasiuka fundamentalny - prowadzi do wniosku, że społeczność wiejska przedstawiona przez pisarza nie wypracowała własnych rytów oczyszczenia. Więcej nawet: cała ta społeczność żyje w stanie głębokiego rozdwojenia, składającego się z amoralnych praktyk codziennych i nieistotnych obrzędów odświętnych. Zwierzęta nie powinny odczuwać potrzeb eschatologicznych, a nawet gdyby je odczuwały, nie mogą same dopełnić obrządku, bo przecież wykopały swoim życiem codziennym głęboką przepaść oddzielającą je od porządku religijnego. Stasiuk komponuje jednak scenę prawdziwie niesamowitą: jest sobota, w kościele pustki, sierżant z rozpaczą prosi ducha, by nie upierał się przy „porządnej mszy” („Rany boskie, Kościejny, bądźże człowiekiem", OG 115), ale ten nie chce ustąpić; policjant zgarnia więc z pobliskiej knajpy siedzących tam pijaków, złodziei, malwersantów i prowadzi ich do kościoła.

Scena w kościele (OG 116-117) kondensuje wszystko, co nie mieściło się w portretach osobnych i w opowieściach gospodarskich: naturę wyposażoną w prerogatywy Boga („światłość wiekuista zachodzącego słońca”), Sąd Ostateczny odprawiany przez żywioły („Obłoki pękały i światło [...] wypełniło 
zręby kościoła jak [...] fala potopu”), a także akt zbawienia („wszyscy na mgnienie stali się przejrzyści jak aniołowie") ${ }^{7}$. Niezwykły - objawiający skalę talentu pisarza - apokaliptyczny i gnostycki splot metafor sugeruje jednak rzecz kluczową: oto następuje zbiorowe rozgrzeszenie, którego wszyscy udzielają sobie nawzajem. Nie może tu zabraknąć ani kościoła, ani żywiołów, ani zwierzęco upodlonej społeczności wiejskiej.

Dokonujące się w tej scenie prawdziwe oczyszczenie staje naprzeciw kapitalistycznej i oszukańczej kreacji nowego świata - opromieniającej ludzi kolorami tanich towarów. Stasiuk podsuwa nam więc wniosek, że kapitalizm oczyści z win PRL-owskich tylko tych, którzy będą mieli coś na wymianę. Reszta, czyli większość, nie ma szans. Stąd właśnie wynika sugerowana przez pisarza konieczność włączenia historii pegeerów, historii wiosek takich jak ta, nie tylko we wspólne dzieje - w historię chłopstwa i powojennego społeczeństwa - lecz także w porządek eschatologiczny ${ }^{8}$. Mówiąc dosadniej: pegeery muszą zostać rozgrzeszone, zyskując absolucję nie tylko od Kościoła katolickiego czy księdza, lecz przede wszystkim od całej społeczności. A podstawą absolucyjnej nadziei jest dokładnie ta sama wartość, którą wszyscy pisarze nurtu chłopskiego uznawali za kluczową dla wiejskiej kondycji, a mianowicie trud - praca nieznająca końca, nieprzynosząca zarobku, który pozwalałby zmienić życie, tożsama z egzystencją i redukująca ową egzystencję do poziomu bydlęcego. Niedopełnienie gestu oczyszczającego wsie pegeerowskie z grzechu amoralności i wyrzucenie ich poza nawias dziejów spowodują - tak można zreinterpretować wątek ducha - że polską historię nawiedzać będzie upiór zwierzęcopodobnego „człowieka stamtąd", folwarcznego parobka, który współtworzył pogardzaną część PRL-u i który wpadł w wyklętą część powojennej historii. Historia według Stasiuka - wbrew Fukuyamie - nie skończyła się w momencie upadku systemu komunistycznego; po tamtej stronie dziejów pozostały „zbłąkane dusze”, które będą nawiedzać każdą przyszłość, dopóki mieszkańcy III RP nie zechcą poprosić ludzi z pegeerów o przebaczenie i sami go pegeerowym duszom nie udzielą.

7 Zob. M. Orski AndrzejStasiuk: alegoryczne theatrum wspólnoty, w: tegożAutokreacje i mitologie, Okis, Wrocław 1997, s. 55-56: „Proza ta [...] ujawnia przed naszymi oczami ukryte, podskórne i jednak metafizyczne nurty zwyczajnego, powszedniego widnokręgu egzystencjalnego".

8 „llekroć o nim myślę, zastanawiam się, czy został zbawiony. On i rzesze jemu podobnych. Bo przecież w jakimś sensie byli nowym plemieniem, ludem, do którego nie dotarła dobra nowina ani żaden nowy Paweł apostoł" (OG 13). 
Śmierć pegeerów nastąpiła nie wtedy, gdy rząd podjął decyzję o ich likwidacji. W porządku symbolicznym nastąpiła ona wtedy, gdy pegeerom odmówiono miejsca w historii wspólnej.

\section{Brudne widmo albo:}

\section{"Mówię mu, że wygląda jak część inwentarza"}

Stasiuk miał rację. Nie tylko w tym sensie, że adekwatnie opisał skutki decyzji z początku dekady. Również w tym, że dobrał odkrywczą metaforę. Postanowienie rządu o likwidacji pegeerów przenosiło bowiem do sfery widmowego istnienia kilkaset tysięcy rodzin, a w szerszym ujęciu - mieszkańców kilkuset wsi w całości związanych z pegeerem. Nie istniało spójne określenie, które pozwalało oddać ich byt; z punktu widzenia rynku stawali się bezrobotni, z punktu widzenia państwa - zależni, z punktu widzenia historii - zapóźnieni. Ale ponieważ wszystko to kondensowało się w ich egzystencjach, ciałach, domach, więc stawali się uciążliwymi nieobecnymi. Na tym polegała ambiwalentna i kłopotliwa ontologia, którą reprezentowali: ich niejasnemu i wyraźnie niepełnemu obywatelstwu przeczyła wielość i wielkość liczb rodzin, gospodarstw, wsi, długów. Gdyby zniknęli, można by ich „oddłużyć”. Jako dłużników, nie można ich było wykreślić z rejestru. Stworzono z nich zbiorowe widmo.

Duch, wampir, upiór mają w polskiej kulturze co najmniej od romantyzmu mocną egzystencję, ale nigdy jeszcze ich dwuznaczna ontologia nie objęła kilkumilionowej społeczności. Jeśli jednak Stasiuk odwoływał się do dziadów i przeprowadzał plebejski obrządek oczyszczenia zbłąkanej duszy, to dyskurs dominujący w prasie kształtował wizerunek chłopów jako upiorów. Zamiast „wysłuchania” i „spełnienia prośby”, starano się retorycznie uśmiercić widmo. Leksykonem prasowych i telewizyjnych doniesień rządził przedrostek „re-”. Chłopów oskarżano o dążenie do rekomunizacji, renacjonalizacji, redystrybucji. Wszystkie te wyrazy potwierdzały upiorną egzystencję mieszkańców wsi, którzy jawili się jako reminiscencja z minionej epoki, jako nieuprawniona retardacja w wartkiej opowieści o kapitalizmie. Chłopi chcieli dopłat do żywności, gwarancji skupu, anulowania długów, a wszystko to, jako

9 Zob. M.D. Zdort Przed chłopską rewolucjq , "Życie Warszawy" 14.07.1992: "Każda partia chłopska w parlamencie czy poza nim w rzeczywistości jest [...] związkiem zawodowym rolników, roszczeniowym i bezkompromisowym w domaganiu się ulg, preferencji i umarzania kredytów dla swoich członków". Podobnie pisał Michał Zieliński, Chłopska droga do kapitalizmu, "Tygodnik Powszechny" 02.05.1993. 
równoznaczne z koniecznością upaństwowienia rolnictwa, było działaniem na rzecz dziejowej repetycji.

Z punktu widzenia poetyki opisowej wydarzyła się w polskim życiu publicznym awaria narracyjna: rząd nie potrafił dopisać dalszego ciągu do opowieści o urealnieniu kredytów i zlikwidowaniu dotacji. Nie to było złe, że podjęto mocne decyzje wpływające na życie kilku milionów ludzi, lecz to, że potraktowano "ciąg dalszy” jako ich prywatną sprawę. A także to, że z uporem godnym lepszej narracji uznawano rolników za wyjątek od reguły - część obcą całemu społeczeństwu, niezdolną zaakceptować nowych warunków gry, stającą w poprzek historii, żądającą powrotu starych czasów. Dlatego z punktu widzenia ontologii życia społecznego stało się coś poważniejszego: upiór się umasowił i wyszedł na drogi. W roku 1990 rolnicy przeprowadzili około tysiąca blokad; w kolejnych latach nie urządzali ich więcej, lecz staranniej wybierali szosy - zwłaszcza dojazdowe do Warszawy ${ }^{10}$. W końcu najechali stolicę traktorami i wylali gnojowicę pod Sejmem.

Zbiorowe widmo dążyło więc do tego, by udowodnić, że jest materialne. I zatykało swoją brudną materialnością drogi, właziło w walonkach do urzędów, zajeżdżało traktorami pod Sejm. Sposób postępowania wobec kłopotliwie śmierdzącego widma zanalizować można na przykładzie dominujących narracji, jakie wykształciły się wokół dwóch najwyrazistszych wiejskich bytów lat 90. - wsi popegeerowskiej oraz Samoobrony. Narracje te miały charakter performatywny: kształtowały przedmioty, rzeźbiły ich wygląd, uczyły odbiorców sposobu postrzegania i w obiegu komunikacyjnym zwrotnie oddziaływały na przedmiot przedstawienia, wytykając mu cechy wadliwe i zadając drogę poprawy.

Apogeum modelowania wsi popegeerowskiej przypada na rok 1997 - moment najostrzejszych wystąpień chłopskich w całej dekadzie i najsurowszej kary ikonograficznej. Wymierzył ją film Ewy Borzęckiej Arizona. Ten trzykwadransowy quasi-reportaż był jak proces sądowy, wyrok i egzekucja w jednym. Film przedstawiał wieś z województwa słupskiego (tego samego, z którego pochodził Andrzej Lepper): na ekranie widzieliśmy niezróżnicowanych ludzi, podobnych pod względem stroju, kondycji i zachowań. Ich podstawowym zajęciem jest nicnierobienie: rozmawiają przy drodze, plotkują, skarżą się, donoszą na siebie nawzajem (dawny informator MO teraz donosi nowej policji),

10 W styczniu 1999 roku ponad 3 tysiące związkowców zablokowało polsko-niemieckie przejście graniczne w Świecku; 27 maja tego samego roku w całym kraju przeprowadzono równocześnie około dwustu blokad dróg. 
szpiegują sąsiadów. Mekką społeczności jest miejscowy sklepik, w którym za gotówkę bądź "na zeszyt” wszyscy nabywają wino Arizona. I piją. Piją na okrągło, cały czas, bez przestanku. Nie odkładają picia do soboty czy choćby do wieczora. Oddzieleni od rzeczywistości płynną błoną alkoholu wiodą życie w bezczasie - w taniej półnieważkości, $w$ bełtowym transie. Ich zwaliste ciała wymykają się prawom fizyki: rozchwiane alkoholem zataczają się od lewa do prawa, zajmując całą przestrzeń drogi i uzmysławiając brak jakiegokolwiek innego ruchu. Nie przejedzie ich samochód, bo żaden samochód tu nie przyjeżdża. Nie zamarzną przy drodze, bo przez lata bumelowania w pegeerze uodpornili swoje ciała na alkohol i na mróz. Są na poły nieśmiertelni, choć zarazem półmartwi.

Z punktu widzenia konsensusu demokratyczno-kapitalistycznego chłopi ze wsi Zagórki zostali przedstawieni jako przeciwmodel nowego obywatela i nowej społeczności: żyją z zasiłku, biernie oczekują na polecenia bądź pomoc z zewnątrz, nie chcą poszukać nowej pracy, nie mają przywódcy, nie potrafią się zjednoczyć, nie ma wśród nich wyróżniających się jednostek. Niesamodzielni, niezdolni do działań produktywnych bądź politycznych, pełni agresywnej nostalgii i progresywnych roszczeń, są nie tylko sami sobie winni, lecz także stanowią dla innych obciążenie i potencjalne zagrożenie.

Jeszcze gorzej wypadał portret chłopów z punktu widzenia kapitalistyczno-liberalnej ideologii ciała wkraczającej dynamicznie do polskiego życia publicznego w latach 9o. Mieszkańcy Zagórek skumulowali w sobie zakazane sprzeczności: ich ciała są biedne i zarazem rozrzutne, zaniedbane i obnażone, włączone w wir identycznych działań i bezproduktywne. Zamiast kumulować energię potrzebną do zmiany swojego życia, trwonią ją na codzienne rytuały bezsilności; zamiast zadbać o wygląd, obscenicznie wystawiają na widok publiczny stan żenującego zapuszczenia; zamiast dostosować się do nowych reżimów cielesnych, praktykują mechanicznie dotychczasową gospodarkę marnotrawienia czasu i ciała.

Kondensacja przewin wobec demokracji, liberalizmu i kapitalizmu następowała tu jako przekroczenie nowych norm widzialności"1. Prosty, choć okrutny wniosek, jaki płynął z filmu, sugerował, że chłopi są klasą niepa-

11 Zob. M. Szcześniak Normy widzialności. Tożsamość w czasach transformacji, Fundacja Bęc Zmiana, Instytut Kultury Polskiej UW, Warszawa 2016. Autorka skupiła się na modelowaniu wizerunku przedstawiciela klasy średniej oraz osoby homoseksualnej. Dodać można, że wizerunek klasy średniej kształtował się nie tylko poprzez naśladowanie wzorców zachodnich, lecz także w ramach panicznej ucieczki przed wyglądem wiejskim. 
nującą nad swoją cielesnością: pozostawieni bez „pana”, który mówiłby, co i w jakiej kolejności mają robić, sami siebie zredukowali do stanu wegetatywnego. Muszą więc albo zniknąć, albo oddać swoje życie w ręce nowego "pana" - osoby zarządzającej pracą i nakazującej nowe praktyki cielesne.

"Chłop w rękach nowego zarządcy" - to właśnie opowieść o Andrzeju Lepperze. Jego wizerunek od samego początku wpisywano w narrację o przemianie. Opowieściom towarzyszyła nadzieja, że tkwiący w chłopie prymitywizm może zostać ucywilizowany. Na rewersie nadziei czyhało jednak przekonanie, że chłopska wegetatywna siła, pożyteczna wyłącznie w pracy na roli, prędzej czy później da o sobie znać i objawi się pod postacią niereformowalnego, przyrodzonego chamstwa.

W taki wzorzec narracyjny ujęto biografię Andrzeja Leppera. Prostak, warchoł, cham, który rozpoznał kreacyjną siłę mediów i został pospiesznie - choć powierzchownie - stworzony przez specjalistę od wizerunku publicznego. Narracja ta mówi zatem, że Lepper nie reprezentował „sam z siebie” żadnej wartości i nie występował w imię prawdziwej sprawy; był przeciętnym nikim, który nigdy nie dostałby się do Sejmu, gdyby nie ekspert od PR-u Piotr Tymochowicz. To on u schyłku lat 9o. przechwycił "surowego" chłopa - krępego, przysadzistego, źle uczesanego i żenująco ubranego, niepotrafiącego przemawiać skutecznie, niepanującego nad rękami i ciałem. Jak profesor Higgins dzięki półrocznej pracy zamienił Elizę Doolittle z kwiaciarki w damę, tak Tymochowicz przeobraził nieokrzesanego prostaka w polityka:

Ekspert podchodzi do niewysokiego, krępego, ubranego w długą kurtkę i sweter, z grzywką wystającą spod czapki, przewodniczącego Samoobrony.

Dwa tygodnie później Lepper, odmieniony, przyjdzie do studia [...]. ${ }^{12}$

Ekspert ordynuje zmianę fryzury („Mówię mu, że wygląda jak część inwentarza. Nie obraża się, prosi o konkrety. Mówię, że ma fryzurę jak spod garnka, a on: «Zmieniajmy, już!»”, Lepperiada, 9), nakłada strój zależny od publiczności („na spotkanie z rolnikami wystarczy średniej jakości marynarka, a nie markowy garnitur”, 9), doradza występowanie bez żony („po zmianie 
wizerunku za mocno od niej odbił”, 9) i kieruje do solarium („Uznaliśmy, że lepszy Mulat niż burak", 13).W 2000 roku z taśmy produkcyjnej Piotra Tymochowicza schodzi gotowy produkt - nowy, lepszy Andrzej Lepper.

Uznano go za "normalnego polityka” dopiero wtedy, gdy jako wicepremier rządu (koalicja: PiS, Samoobrona, Liga Polskich Rodzin, 2005-2007) zagroził rolnikom sankcjami karnymi za ewentualne blokowanie dróg i niespłacanie kredytów. Ale nie wytrzymał próby czasu: odkryta przez Marcina Kąckiego afera „praca za seks”, a także ujawnienie rozległego procederu korupcji i nepotyzmu połączonego ze skrajną niekompetencją uruchomiły lawinę, która zgniotła Samoobronę, a kilka lat później popchnęła Leppera do samobójstwa. Książka zasłoniła jednak ekonomiczne problemy wsi obyczajowym skandalem. Dlatego brawurowa Lepperiada legitymizowała klasową odrazę skrytą w protekcjonalnym fatalizmie, który mówił, że chłopa nie da się ucywilizować. Spod markowej marynarki i opalonej twarzy prędzej czy później musiała wyłonić się prawdziwa twarz prostaka niepotrafiącego trzymać swoich popędów na wodzy ${ }^{13}$.

Pod powierzchnią rozlicznych różnic między Arizoną i opowieściami o Lepperze dominują podobieństwa. Jeśli Arizona ukazywała chłopa jako niezdolnego do liberalnego i kapitalistycznego urealnienia ciała jednostkowego, czyli poddania ciała samodzielnemu zarządzaniu, to opowieść Kąckiego przedstawiała chłopów jako niezdolnych do demokratycznej materializacji ciała zbiorowego ${ }^{14}$. Ciało Samoobrony nigdy nie stało się partią, pozostając raczej "gromadą", a więc bytem nieforemnym, niezdyscyplinowanym, nieucywilizowanym, niepotrafiącym trzymać swoich otworów i penisów w ryzach, wylewającym się ustawicznie poza własne granice i naruszającym granice cielesności cudzej.

W narracjach modelujących chłop jest więc ukazywany jako człowiek niezdolny do przetworzenia swojej „prawdziwej” cielesności. Jego strój to maska, która po opadnięciu obnaża prawdę o niewolniku wymagającym „pana”, niezdolnym do samodzielnego kontrolowania swoich odruchów, nieznającym umiaru w nabywaniu dóbr, nie tyle więc oszczędnym na zapas, co pierwotnie

13 Stefan Chwin w eseju Droga na Belweder („Krytyka Polityczna” 2003 nr 4) przedstawił Leppera jako współczesne wcielenie Artura Ui. Bardziej wyważone ujęcie - zob. M. Drozd-Piasecka Andrzej Lepper - chłopski przywódca charyzmatyczny?, „Etnografia Polska” 2001, t. 45, z. 1-2.

14 O przemianach zbiorowych postaw rolników i mieszkańców wsi wobec państwa zob. K. Szafraniec Polskie residuum systemowe, czyli pytanie o rolę wsi i chłopów w procesach przekształceń ustrojowych, "Kultura i Społeczeństwo” 2002 nr 4, s. 19. 
chciwym $^{15}$. Charakterystyka chłopa w polskich narracjach polega więc na urasowieniu klasy, czyli uznaniu, że pochodzenie klasowe funkcjonuje jak rasa, determinując mentalność i odruchy ciała.

Narracje zachęcające klasę chłopską do autodemontażu, zacierające skalę skutków likwidacji własności państwowej i spółdzielczej ${ }^{16}$, pochwyciły swoje przedmioty w kleszcze widmowej reprezentacji: jeśli chłop nie chciał poddać swojego ciała nowym obrządkom oczyszczenia (produktywność, schludność, samodzielność), stawał się brudnym widmem pegeerów, jeśli wybierał nowe reżimy cielesności zbiorowej, urealniał się w cudzym ciele (fryzura, garnitur, opalenizna) i stawał się czystym widmem polityki, które nie może reprezentować chłopskiego buntu. W pierwszym przypadku występował jako statysta we współczesnej „satyrze na leniwych chłopów”, w drugim służył jako przykład fałszywej przemiany „z chłopa - polityk”. Brudne widmo chłopa albo więc nie podlegało oczyszczeniu, albo po oczyszczeniu odradzało się jako reprezentant interesów produkcji.

\section{Śmierć po raz drugi}

Raz jeszcze należy się cofnąć do połowy lat 90. - dla omówienia powieści Olgi Tokarczuk Prawiek i inne czasy ${ }^{17}$.

Książce nie poskąpiono złośliwych recenzji. Mimo to nie sposób pominąć jej przy omawianiu tematyki wiejskiej w nowym okresie. Na przekór dąsom krytyków ${ }^{18}$ Prawiek okazał się - na dobre czy złe - powieścią wzorotwórczą, niemal równie wpływową, co w latach 60. i 70. proza Myśliwskiego czy Nowaka. Wynikało to prawdopodobnie z prostego pomysłu: autorka wykorzy-

15 Przypisywanie tej cechy wyłącznie chłopom ma w polskiej kulturze charakter projekcyjny, zob.

J. Wasilewski Społeczeństwo polskie, społeczeństwo chłopskie, "Studia Socjologiczne” $1986 \mathrm{nr}$ 1, s. 52.

O strukturze własności rolnej w PRL i w III RP zob.: J.S. Zegar Kwestia gospodarstw samozaopatrzeniowych w Polsce, „Wieś i Rolnictwo” 2007 nr 1; J. Wilkin Struktura wsi i rolnictwa - Polska, w: Chłop, rolnik, farmer? Przystapienie Polski do Unii Europejskiej - nadzieje i obawy polskiej wsi, Instytut Spraw Publicznych, Warszawa 2000, s. 34-52.

17 Cytaty wg wydania: O. Tokarczuk Prawiek i inne czasy, Wydawnictwo W.A.B., Warszawa 1996. Lokalizacja przytoczeń bezpośrednio $w$ tekście po literze P. kiej powieści", zob. K. Uniłowski Cała prawda o prozie środka (2), „FA-art” 2002 nr 4, s. 32. Dariusz Nowacki nazwał Prawiek i inne czasy "banałem ekologicznym i innymi popierdami z mchu i paproci" (cyt. za: K. Uniłowski Cała prawda..., s. 32). 
stała strukturę wielopokoleniowej sagi rodzinnej, wprowadzając do niej - co stanowiło rzeczywiste novum - silną konfrontację płci.

Posłużyło to pisarce do stworzenia opowieści o zaniku wsi - tej konkretnej i tej uogólnionej. Abstrahując od schematyczności postaci i ich losów, a także nie wdając się w streszczanie całości, można wyliczyć figury owego zaniku: skończył się czas wioski polsko-żydowskiej, czas ziemiaństwa decydującego o ekonomii wsi, czas kościoła posiadającego ziemie uprawiane przez chłopów, czas rodzin płodzących i wychowujących dość dzieci, by urodzeni wyrównali śmiertelność i straty migracyjne. Co pokonało tę wieś? Wcale nie dwie wojny i czasy komunizmu, lecz, niemal przeciwnie, anachroniczne trwanie struktury społecznej i własnościowej. Struktura została przez powojenną Polskę napełniona na nowo, ale zachowała swój folwarczny charakter. Wieś ukazana przez Tokarczuk żyje bowiem po wojnie w historycznym poślizgu, jakby jej mieszkańcy nie zauważyli, że dawnej struktury już nie ma i że powinni przeorganizować życie na nowo. Nie ma już Żydów, ziemiaństwa, kleru, zmieniła się pozycja młynarza, przetrwała jednak folwarczna relacja między męskim i kobiecym oraz ludzkim i pozaludzkim. Kres dawnego porządku został więc wywołany przez jego własnych funkcjonariuszy, którzy uważali, że podstawowym zadaniem mieszkańców wsi jest zreprodukowanie dawnej hierarchii w nowym ustroju. Dzieci, które skorzystały z prawa wyboru i bezpowrotnie opuściły wieś, osłabiły mechanizm reprodukcji i skazały całość na powolną śmierć. W tym sensie Olga Tokarczuk opowiedziała o wsi, która funkcjonowała po wojnie jako systemowy bufor, osłabiający radykalność zmian ustrojowych ${ }^{19}$. Spowolnienie łudziło wrażeniem niezmienności, ale działało usypiająco i nie pozwalało dostrzec, że cała struktura powojennej wsi jest widmem minionej historii.

Prawiek... przekonuje jednak, że życie jest nie tyle gdzie indziej, ile w czym innym. Lepszego życia nie ma w miastach bądź innych krajach, dokąd udają się niektórzy bohaterowie powieści. I nie jest też tak, że owo życie skryte w czym innym jest lekceważone czy niszczone przez stronę męską, dostrzegane zaś i pielęgnowane przez stronę kobiecą. Rację w tej powieści, rację nader łagodną, ma jak się zdaje narrator, który odsłania inny - oikologiczny - model istnienia, którego wzorcem jest grzybnia. Zakłóca ona wyraziste podziały („nie jest ani rośliną, ani zwierzęciem”,, ,jest życiem śmierci, życiem rozkładu”, P 170), kwestionuje hierarchie („nie dzieli i nie wyróżnia swoich dzieci”, P 171)

19 Zob. K. Szafraniec Polskie residuum systemowe, czyli pytanie o rolę wsi i chłopów w procesach przekształceń ustrojowych, "Kultura i Społeczeństwo” $2002 \mathrm{nr} 4$. 
i żyje dzięki przenikaniu się z innymi istnieniami. Grzybnia nie broni swoich granic przed innymi roślinami, a zarazem korzysta z ich życia. Nadużywając nieco pojemności tej metafory, można powiedzieć, że grzybnia jest matrycą innej sieci istnienia - neutralizującej podziały płciowe, nastawionej w większym stopniu na równość niż hierarchię, na współpracę, a nie na wyzysk, na solidarność, a nie na konkurencję. Jeśli wieś umarła, to dlatego, że nie potrafiła zmienić modelu życia, choć alternatywę dla matrycy folwarcznej mieszkańcy mieli pod bokiem.

Po Prawieku... literatura o wsi wchłonęła pytanie dotyczące podziałów płciowych i przydziału obowiązków z tym związanych ${ }^{20}$. Przyswoiła sobie także pomysł poszukiwania innej sieci istnienia zdolnej połączyć mieszkańców i mieszańców.

W tym kontekście usytuować można powieść Jakuba Małeckiego Dygot ${ }^{21}$, która wykorzystała identyczną strukturę sagi rodzinnej. W ramach owej sagi poznajemy losy trzech pokoleń wiejskich rodzin - Łabendowiczów i Geldów. Prawidłowością generacyjną jest awans społeczno-przestrzenny: najstarsze pokolenie żyje na wsi ${ }^{22}$, średnie przenosi się do małego miasteczka (Koło), najmłodsze migruje do dużego miasta (Poznań). Silniejsze jednak od linii wznoszącej są podziały genderowe. Wieś oglądana z perspektywy męskiej niczym nie różni się od miasta: historia przychodzi do wsi, zakłada prąd i urządza szkołę, wysyła dzieci na naukę; przeprowadzka na stałe do miasta nie jest żadnym awansem, ponieważ wszędzie czyha nicość i wszędzie „dygot” popycha mężczyzn do autodestrukcji. Z punktu widzenia kobiecego „dygot” ten jest rzeczą normalną - jak śmierć czy seks - więc trzeba sobie radzić z nicością, powtarzając czynności wyuczone i zarazem starając się wprowadzić w nie drobną odmianę. Z męskiej perspektywy wieś umarła, bo ludzie uciekli przed nicością w objęcia miejskich wygód, z perspektywy kobiecej wieś umiera, ponieważ męskie gospodarowanie „dygotem” wypchnęło kobiety do miast.

20 Przejmującym i przekonującym oskarżeniem wiejskiego patriarchalizmu - składającego się z opieki nad kobietami, ale też z gwałtów, przemocy i wyzysku - jest w nowszej literaturze powieść Ewy Ostrowskiej Owoc żywota twego (2004). A ciekawym potwierdzeniem niszczącego wpływu kultury patriarchalnej na społeczność wiejską pozostaje powieść Daniela Odiji Niech to nie będzie sen (2008). J. Małecki Dygot, Wydawnictwo SQN, Kraków 2015 [IBooks 2016]. Lokalizacja przypisów bezpośrednio w tekście po skrócie: Dygot. 
Powieść, światopoglądowo pretensjonalna, a genderowo samobójcza, właśnie dlatego warta jest włączenia do rozważań, że znamionuje moment upowszechnienia się kategorii płci kulturowej w narracji o wsi. Dygot sprawia przecież wrażenie mrocznej wersji Prawieku... - trzypokoleniowej sagi o awansie i zamieraniu tradycyjnej wsi. O ile jednak Olga Tokarczuk wskazywała na życie tkwiące w innym wiązaniu sieci istnień, o tyle Małecki takiej szansy i takiej nadziei konsekwentnie swoim bohaterom i swojemu światu odmawia. Autor jednak nie zauważył, że chcąc napisać powieść o uniwersalności mrocznej siły pożerającej sens, sporządził spóźniony o dwadzieścia lat powieściowy dowód, że umieranie wsi jest skutkiem nie tyle nowoczesnego postępu, co raczej konserwatywnego nihilizmu szukającego wzniosłości w męskim umieraniu.

\section{Pejzaż widm}

Z dotychczasowych rozważań wynika, że w polskiej prozie po roku 1989 pisanie o wsi spełnia się w obszarze nekrografii - zróżnicowanych poetyk służących mówieniu o śmierci. Dla wyjaśnienia nieoczekiwanego sojuszu prozy przedstawiającej wieś z nekropoetykami można posłużyć się obrazem kulturowego starcia. Oto w kulturze polskiej w latach 9o. doszło do spotkania nowych dyskursów politycznych z nowymi poetykami literackimi. Z jednej strony pojawiły się zatem dyskursy: demokratyczny (o nowych formach indywidualnej i zbiorowej partycypacji politycznej), liberalny (o nowych sposobach zarządzania własnym życiem poprzez aktywne gospodarowanie ciałem) i kapitalistyczny (o ekonomizacji życia). Spotkały się one z literackimi opowieściami o marnotrawnej gospodarce, o porządku społecznym opartym na męskiej przemocy, o patriarchalnych wzorcach życia wypychających kobiety ze wsi i blokujących konstruowanie nowych sieci życia.

Wynik spotkania prowadził do ponurego wniosku: trwanie kultury chłopskiej okazywało się niewyobrażalne zarówno w postaci dotychczasowej, jak i w postaci zmodernizowanej. Skromna subwersja literatury polegała na tym, że ukazywała wieś zamienianą w widmo nie tylko przez transformację ustrojową, lecz także przez tradycyjną kulturę chłopską.

Dochodząc od tej strony do drugiej dekady XXI wieku ${ }^{23}$, zyskuję możliwość wyjaśnienia, dlaczego najciekawsze dzieła dotyczące wsi mają charakter ghost stories.

23 Dzieła należące do nekropoetyk wiejskich pojawiały się już w pierwszej dekadzie. Zaliczyć do nich można narracje zstępne, mówiące o przejmowaniu od wiejskich przodków (najczęściej 
Ludzka rzecz (2013) Adama Potoroczyna, Guguty (2014) Wioletty Grzegorzewskiej, Sońka (2014) Ignacego Karpowicza, Uprawa roślin potudniowych metoda Miczurina (2015) Weroniki Murek, Mała zagtada (2015) Anny Janko, Podkrzywdzie (2015) Andrzeja Muszyńskiego to sekwencja narastającej upiorności. Efekt widma przejawia się najwyraźniej w książkach mówiących o dawnej, zbiorowej śmierci (Janko), która nawiedza trzecie już pokolenie; albo przedstawiających opustoszałą wieś (Karpowicz), w której żyje - co boleśnie wyostrza wymowę pustki - ostatnia mieszkanka.

U Karpowicza i Janko istnieje jednak nadal stosunkowo wyrazista różnica między życiem i śmiercią. Novum pozostałych wymienionych książek polegało na zatarciu granicy. Ludzka rzecz zaczyna się od śmierci partyzanta Smyczka, a kończy pośmiertnym kazaniem księdza, który nad zwłokami bohatera mówi:

- Panie chorąży Smyczek! Dla Boga, panie Smyczek! Larum grają! Wojna! Nieprzyjaciel w granicach! A ty się nie zrywasz? Szabli nie chwytasz? Na koń nie siadasz? Co się stało z tobą, żołnierzu? Zaliś dawnej przepomniał cnoty, że nas samych w żalu jeno i trwodze zostawiasz? Kościoły, o Panie, zmienią w gorzelnie i kuplety śpiewać będą tam, gdzieśmy dotychczas Ewangelię śpiewali. ${ }^{24}$

Pomiędzy śmiercią i kazaniem toczy się brawurowa, przetykana dygresjami i opowieściami biograficznymi historia potyczek z Niemcami prowadzonych przez dwa konkurujące ze sobą oddziały partyzanckie. Wieś Piórków, w której rozgrywa się akcja, jest nie tyle konkretnym miejscem ${ }^{25}$, co raczej bytem językowym i literackim, w którym - dzięki rozlicznym zabiegom stylizacyjnym (gawęda szlachecka, powieść łotrzykowska, romans, ballada) mieszają się biografie, narodowości, hierarchie. Kończąca całość parafraza

dziadków) dziedzictwa, które nie ma już bezpośrednich dziedziców. Przykładem są Oberki do końca świata (2007) Wita Szostaka - historia młodego muzyka, który przejmuje muzykę ludową od zmarłych przodków (w sensie dosłownym: w ostatniej scenie powieści główny bohater odnajduje wreszcie własny rytm grania na wiejskich skrzypcach, ale dzieje się to w izbie, w której jego dziadkowie siedzą martwi). Późny debiut, ludzka rzecz, ",Kultura Liberalna” $2013 \mathrm{nr}$ 37, http://kulturaliberalna.pl/2013/09/02/ majchrowska-pozny-debiut-ludzka-rzecz-o-powiesci-pawla-potoroczyna/(11.08.2017): D. Nowacki Dawno temu pod Częstochową, "Gazeta Wyborcza" 23.04.2013: 
pamiętnej mowy księdza Kamińskiego nad trumną Wołodyjowskiego oznacza, jak się zdaje, śmiały wślizg z trumną chłopskiego partyzanta do polskiej pamięci zbiorowej zdominowanej przez wzorce szlachecko-sarmackie. Sam autor - wielokrotnie wtrącający się do swojej opowieści - podważa jednak skuteczność owego gestu i sugeruje, że nie istnieje w polskiej kulturze nic takiego, jak uniwersalna „ludzka rzecz”: kultura klasowa uwzględnia nie działania, lecz pochodzenie, stąd uszlachcenie chłopa jest możliwe tylko wtedy, gdy wpisuje się on w czyn narodowowyzwoleńczy i gdy w ramach owego czynu ponosi śmierć. Aby chłop był żywy w pamięci narodowej, musi być heroicznie martwy - co prowadzi do kolejnego wniosku, mówiącego, że wieś, pomijana w historii od czasów Polski szlacheckiej, należy do innej „rzeczy ludzkiej” niż reszta społeczeństwa ${ }^{26}$. Nawiązanie do Trylogii jest próbą zapobieżenia powrotnemu przesunięciu wsi do rejestru osobnego, ale próbą dwuznaczną, ponieważ umieszczenie chłopa na sarmackim katafalku oznacza, że kultura chłopska sama się nie obroni. Chcąc temu przeciwdziałać, powieść wchłania style istniejące i zmyślone, działając jak maszyna destylizacyjna: celem jest pomieszanie języków kultury wyższej, aby kultura ta, tracąc zdolność przydzielania stylów, utraciła zdolność dystrybuowania wartości. Powieść Potoroczyna nie wprowadza wyrazistej poetyki, ale ujawnia automatyzmy, które zarządzają kulturą wiejską.

Językowa przygoda z Ludzka rzecza polega na tym, że czytelnik przedziera się przez plątaninę poetyk otaczających widmową kryptę kultury wiejskiej. Niepomiernie silniejsze zwątpienie ontologiczne panuje w narracji Weroniki Murek: od początku do końca nie wiemy, czy jesteśmy na wsi, w małym miasteczku, czy na przedmieściach miasta większego; czy akcja dzieje się w jednym roku, czy raczej obejmuje całą powojenną historię; czy postaci, które poznajemy, są żywe, czy umarłe. Jednoznaczne rozstrzygnięcia są tu niemożliwe, więc kluczowe okazuje się wskazanie przyczyny rozmywającej wszystkie granice - z granicą między życiem i śmiercią włącznie. Sądzić można, że ową siłą deontologizującą świat jest specyficzna dla polskiej historii powojennej fuzja katolicyzmu i nowoczesności. Religia znaturalizowała obcowanie z transcendencją, nowoczesność natomiast (w powieści reprezentowana przez kontrolę urodzeń i wychowania, powszechne szczepienia, loty

26 W dwóch obszernych monografiach nt. dziejów Polski: M. Markiewicz Historia Polski 1492-1795, Wydawnictwo Literackie, Kraków 2004; U. Augustyniak Historia Polski 1572-1795, PWN, Warszawa 2008 - chłopom, stanowiącym do XIX wieku 80 procent społeczeństwa, poświęcono: w pierwszej 6 stron na 750, w drugiej - 4 na 100o! O dysproporcji tej zob. D. Łukasiewicz Apologia sarmatyzmu i upadek Polski, ,Le Monde Diplomatique - Edycja Polska” 2015 nr 12, s. 43. 
w kosmos, samochody, komunikację radiową, Internet) zdenaturalizowała przyrodę ${ }^{27}$. Mówiąc inaczej: katolicyzm rozmył granicę między światem i zaświatem, nowoczesność - między stałym i zmiennym. Wieś - niczym układ probierczy całej Polski - połączyła oba paradygmaty i zaludniła się widmami.

Z perspektywy omawianej sonaty widm kwestia wymierania wsi nabiera więc nieco bardziej złożonego charakteru. Jeśli pierwsze narracje mówiły o transformacji jako wyroku śmierci wydanym na wieś, a pierwsze teksty rewizyjne dodawały do tego analizę wiejskiego tradycjonalizmu jako czynnika współpracującego z wymieraniem, to książki omówione w niniejszej części wydłużają perspektywę. Sięgają bezpośrednio do wojny, a pośrednio w głęboką przeszłość, ukazując polską kulturę jako producentkę widmowego istnienia wsi. Przybierało ono postać wsi zależnej, służebnej i dyskursywnie niesamodzielnej ${ }^{28}$. Paradoks odsłonięty przez pisarzy wyrażał się w tym, że najskuteczniejszą formą obrony przed kulturową dominacją okazywało się przekształcanie wsi w widmo. Jeśli zatem literatura przełomu XX i XXI wieku szukała szans odnowienia energii wiejskiego życia, to pisarze następnej dekady z groteskowym zaciekawieniem odkrywali przede wszystkim energię śmierci.

\section{Inne życie}

Wieś się nie wyludnia. Nie wymiera. Nie przestaje produkować.

Kładę powyższe zdania na początku ostatniej części dla przywołania oczywistości, które nakazują skomplikować dotychczasowy wywód.

W 1946 roku wieś zamieszkiwało 15,5 miliona ludzi; w roku 2007 14,8 miliona. Nie oznacza to, że przez cały okres powojenny wieś stabilnie

27 Tytuł powieści odsyła do radzieckiego hodowcy i sadownika Iwana Miczurina (1855-1935), który sądził, że poprzez odpowiednie kombinacje człowiek może niemal dowolnie przeobrażać przyrodę. Weronika Murek wykorzystała w charakterze motta znaną sentencję przypisywaną Miczurinowi: "Nie możemy czekać na łaskawość przyrody. Naszym celem jest wziąć ją od niej samemu" (Uprawa roślin południowych metodq̨ Miczurina, Wydawnictwo Czarne, Wołowiec 2015, s. 7).

W samym środku widmowego apogeum Wiesław Myśliwski w eseju Rozważania o kulturze chłopskiej („Kultura Wsi” 2014 nr 1, s. 31) stwierdzał: „chłopi polscy przez wieki nie byli obywatelami Polski. Byli ludnością w najlepszym razie drugiej lub trzeciej kategorii. Chłopi polscy nie należeli do narodu. Chłopi polscy byli izolowani od spraw państwa, od jego kultury". Zob. także M. Vogt-Kostecka Żywe nam nie przepuści. Przyczynki do hodowlanej historii Polski , "Czas Kultury" 2016 nr 3, s. 86. 
reprodukowała swój stan ludnościowy, lecz że przez cały ten okres oddawała miastu nadwyżkę demograficzną. Mimo tego wydatku odsetek ludności wiejskiej w ostatnim okresie nieznacznie wzrósł: w 2007 roku ludność wiejska stanowiła 38,8 procent populacji kraju, w $2014-39,7$ procent $^{29}$. Nieprawdą jest więc, że wieś się wyludnia i że coraz większa część populacji zamieszkuje w miastach. Nieprawdą jest również, że wieś wymiera z powodu wyjazdu młodych do miast: tendencja migracyjna słabnie od roku 1980, a odwraca się w roku 2000. Od początku wieku XXI więcej ludzi powraca na wieś, niż z niej wyjeżdża! ${ }^{30}$

Mimo to prawdziwe jest stwierdzenie, że wieś znika. Ale przez znikanie należy rozumieć, że przestaje istnieć w dotychczasowej formie: wyludnianie dotyka tereny słabo skomunikowane z miastami, a na obszarach dobrze połączonych wieś zmienia swój charakter, stając się przymieściem, a więc obszarem określanym nie przez pracę na roli, lecz przez produkcję żywności sprzężoną z gospodarką rynkową oraz przez rozwój usług ${ }^{31}$. Przymieście takie przeżywa silne rozwarstwienie społeczne i znajduje się w stanie kulturowo rozmytym, zbliżonym w swojej charakterystyce do małych miejscowości. Wieś znika zatem w swoim dotychczasowym kształcie, a jej nowe oblicze staje się słabo odróżnialne od prowincji.

Równocześnie wieś ma mniej niż kiedyś, mniej niż miasto i mniej, niżby tego pragnęła ${ }^{32}$. Bezrobocie na wsi po roku 1989 zawsze było wyższe niż w miastach, zarobki zawsze niższe, utrata pracy bardziej dramatyczna, znalezienie nowego zatrudnienia - niepomiernie trudniejsze. Między pamięcią dawnego stanu posiadania i oczekiwaniami, między obserwacją rozwoju miast i doświadczeniem zastoju własnego powstaje rozziew. Ze szczeliny tej

29 Dane za: I. Frenkel Struktura społeczno-zawodowa ludności wiejskiej w świetle wyników Spisu 2002, Instytut Rozwoju Wsi i Rolnictwa PAN, Warszawa 2003; Polska wieś 2016. Raport o stanie wsi, red. J. Wilkin, I. Nurzyńska, Wydawnictwo Naukowe Scholar, Warszawa 2016.

Zob. M. Halamska Transformacja wsi 1989-2009: zmienny rytm modernizacji. „Studia Regionalne i Lokalne" 2011 nr 2, s. 5-25.

31 Zob. B. Pięcek Czy wieś polska się wyludnia?, "Wieś i Rolnictwo” 2006 nr 1(130). Autorka analizuje proces, który powoduje, że wsie położone daleko od miasta się wyludniają, a podmiejskie - zagęszczają. Te pierwsze obszary podlegają stopniowej degradacji, drugie się urbanizują i wzbogacają o infrastrukturę pozarolniczą.

32 Tą figurą retoryczną posłużyła się Krystyna Szafraniec, zob. tejże Polskie residuum systemowe, czyli pytanie o rolę wsi i chłopów w procesach przekształceń ustrojowych, "Kultura i Społeczeństwo" 2002 nr 4, s. 22. 
w kolejnych latach wyłaniał się głos prośby, wstydu, gniewu i wściekłości. Ja spróbuję poszukać tam nowej samowiedzy.

Punktem wyjścia owego dążenia do samowiedzy uczynię założenie, że wieś od roku 1989 funkcjonuje jako nieuznany warsztat potransformacyjnej samodzielności - domowych, gospodarskich, przyzagrodowych, jednostkowych i zbiorowych sposobów radzenia sobie w nowych warunkach. Warsztat śmiechu z własnych niepowodzeń i uporu w ponawianiu prób, warsztat rozpoznawania słabości i szukania siły, zrywania układów i tworzenia nowych więzi, brnięcia w głupotę i zdobywania gorzkiej mądrości. Nic na miarę przełomu, wszystko na miarę minimalnego przyrostu życia.

Pierwszym przejawem owej samowiedzy, choć podanym jeszcze w mocno deprymującej poetyce, był film Juliusza Machulskiego Pieniąde to nie wszystko (2001), w której zapijaczona ludność zamieszkująca dawne „pegeerowo”, oddająca się nostalgicznemu wspominaniu „komuny", przechodzi od prostracji do produkcji. Ważne przy tym wydaje się, że mieszkańcy wpuszczą na rynek wino - a więc produkt, który utrzymuje ich w stanie tęsknej bezczynności. Dwuznaczna wymowa filmu (pijaństwo własne zamienić na cudze) nie powinna zasłaniać faktu, że warunkiem sukcesu jest tu uświadomienie sobie wstydliwego stanu i włączenie źródła owego wstydu w rynkową transakcję. Wieś w filmie Machulskiego zyskuje dystans do samej siebie, potrafi się z siebie śmiać i zaczyna rozumieć, że rynek żywi się ludzkimi słabościami.

Lekcja, która wynikała z siermiężnej przygody kapitalistycznej przedstawionej przez Machulskiego, przekonywała również, że konieczne jest wyjście ze stanu izolacji i włączenie się w szerszą cyrkulację - bez czekania na pomoc bądź kolejną porcję wstydu. Właśnie taką przygodę napotkać można w powieści Andrzeja Muszyńskiego Fajrant (2017) - unikatowym przykładzie wiejskiej prozy neokolonialnej. Oto trójka młodych bohaterów po latach ciężkiej pracy i sumiennego oszczędzania w Wielkiej Brytanii wraca (rok 2007) do rodzinnej wsi w Polsce; wieś powoli staje się przymieściem³ ${ }^{33}$. Bohaterowie najpierw próbują rozkręcić innowacyjny program selekcji piłkarzy, ale brakuje im sponsora; potem biorą się za usługi chemiczne (odgrzybianie), ale ponoszą klęskę; wreszcie dwoje z nich jedzie do Chin i Birmy, by wykorzystać (kluczowe dla kapitalizmu neokolonialnego) różnice między kosztami 
produkcji w krajach azjatyckich i europejskich. Biznesmeni u Muszyńskiego wyzyskują przy tym warunki klimatycznej katastrofy i gospodarczej zapaści, co, jak wiemy z rozważań Noami Klein, stanowi moment inicjalny nowego etapu kapitalizmu opartego na „doktrynie szoku”. Po powrocie do kraju główny bohater wchodzi w spółkę z potomkinią przedwojennej (niemieckiej) arystokracji, która zamieszkiwała tę wieś.

Muszyński pokusił się więc o nieco cyniczną utopię posthistoryczną: lokalny kapitał zdobyty na neokolonialnym przedsięwzięciu zostaje dokapitalizowany przez bizneswoman, której dziadkowie byli właścicielami wsi, i ulokowany w globalnej firmie (montaż anten do sieci komórkowych), która we wsi wesprze spółdzielnię pracy. Narracja śmiałym ściegiem łączy dawną zależność folwarczną z teraźniejszą spółką biznesową, neokolonializm z wiejską bazą i korporacjonizm ze spółdzielczymi zasadami produkcji. Nie ma większego znaczenia, czy przedsięwzięcie się powiedzie. Ważne, że - podobnie jak w przypadku filmu Machulskiego - mieszkańcy wsi samodzielnie i metodami chałupniczymi, ponosząc klęski i podnosząc się z nich, testują możliwości włączenia się w szersze sieci.

Ważne też wydaje się, że Muszyński - inaczej niż w powieści Podkrzywdzie (2015) - nie szuka osobnej, nieredukowalnej, niedającej się nigdzie indziej odnaleźć wartości wiejskiej, lecz samodzielności w nowym ustawianiu społecznych relacji. Jak pokazuje Fajrant, pomocna w takim działaniu może okazać się pamięć zbiorowa, w której przechowały się zarówno zasady pracy folwarcznej, jak i reguły pracy w spółdzielni produkcyjnej. Fajrant o tyle jednak jest wypowiedzią wstępną, że nie zakorzenia nowej cyrkulacji pracy i kapitału w samoświadomości mieszkańców i w ich praktykach komunikacyjnych. Te konieczne uzupełnienia można znaleźć w jednej z najciekawszych powieści wiejskich ostatniego okresu - Skoruniu (2015) Macieja Płazy. Zaobserwować w niej możemy równoczesność trzech procesów. Młody bohater, tytułowy Skoruń (leń, łobuz, nicpoń), wdraża się do pracy w gospodarstwie ojca, który jest inżynierem po studiach, a do tego domorosłym Faustem: ulepsza maszyny starsze i konstruuje nowsze, wyposaża gospodarstwo w nowe pomieszczenia, dąży do coraz pełniejszej mechanizacji. Nie jest rolnikiem, lecz sadownikiem, który - i to jest proces pierwszy - stopniowo przekształca podległą sobie przestrzeń z obszaru uprawy ziemi w obszar produkcji żywności. Praca, mechanizacja i usprawnienie to dla niego fetysze, co budzi silny opór w Skoruniu. Prowadzi to do drugiego wątku, a mianowicie więzi międzypokoleniowej, którą udaje się utworzyć dopiero wtedy, gdy syn wchodzi w posiadanie mrocznej tajemnicy ojca (ojciec kiedyś wysadził wał przeciwpowodziowy, 
aby za cenę zalania obszaru już objętego powodzią uratować wieś własną); sama tajemnica nie byłaby tak istotna, gdyby nie zrozumienie, jakie syn dzięki temu osiąga, związane z odkryciem zasady odpowiedzialności (przekraczającej fetysz pracy). Bohater dorasta stopniowo do akceptacji pracy i przyjęcia na siebie odpowiedzialności za rodziców (w ostatniej scenie Skoruń ratuje matkę), wchłaniając kolejne doświadczenia i nadając im - to proces trzeci - postać opowieści. Jego aktywność narracyjna, z punktu widzenia literatury najważniejsza, obejmuje coraz szerszą gamę środków i kategorii; chłopiec uczy się milczenia, pyskowania, pojedynku na słówka, wieczornego opowiadania, wyposażając swoje opowieści w zwykły szczegół i tajemnicę, przemilczenie i dosadność, a także w grozę i piękno.

Oto właściwie finał. Wieś, w latach 9o. zohydzona, zmenelona, utytłana w medialnych obrazkach ukazujących pijacką czeredę nierobów, dorobiła się nowych opowieści i nowej samowiedzy. Gdyby pisarze dawali nam wybór: albo kapitalistyczna sielanka, albo postkomunistyczny horror; albo agroturystyka, albo Lepper, zysk byłby pozorny, a strata poważna. Stawką opisanych przeze mnie pojedynków na języki i poetyki nie było bowiem ustalenie, która ze stron ma rację, ani też znalezienie pomysłu na rozwiązanie problemów wsi, lecz przełamanie impasu komunikacyjnego, polegającego na przepuszczaniu wsi PRL-owskiej do potransformacyjnego życia przez próg wielorakiej śmierci. Samowiedza i więź nie były więc potrzebne wyłącznie wsi. Były i są niezbędne przede wszystkim dla tych, którzy owe narracje produkują i reprodukują. Nasza samowiedza została przeorana, połączenia - odnowione. W tym jest odrobina nadziei na inne życie wszystkich. 


\section{Abstract}

\section{Przemysław Czapliński}

ADAM MICKIEWICZ UNIVERSITY (POZNAŃ)

Death, Death, Another Life: The Village in Polish Literature of Turn of the Twenty-First Century

Exploring the changing position of the village in Polish culture and fiction at the turn of the twenty-first century, Czapliński argues that: 1) the 1990 s see a decline in the literary peasant tradition (due to the loss of symbolic and political representation); in its place we get fiction that thematizes the village; 2 ) in the plot, the double death of the peasant tradition is expressed through the motif of the dying village (depopulation, poverty) as well as the status of the undead (ghosts, spectres) imparted on the village community; 3) only in works of the 2010s, literary representations of the village begin to give rise to new social ties, new methods of production and other narratives.

\section{Keywords}

peasant tradition, village, representation, undead, capitalism, autonomy. 